\title{
Protective Role of $\beta$-sitosterol or Gibberellic Acid to Lycopersicum esculentum Cultivars Under Temperature Stress
}

\author{
S.A. Haroun ${ }^{(1) \#, ~ R . M . E . ~ G a m e l ~}{ }^{(1)}$, J.A. Bashasha ${ }^{(2)}$ and I.A. Aldrussi( ${ }^{(2)}$ \\ (1)Botany Department, Faculty of Science, Mansoura University, Mansoura, Al \\ Daqahliyah, Egypt and ${ }^{(2)}$ Botany Department, Faculty of Science, Benghazi University, \\ Benghazi, Libya.
}

\begin{abstract}
T HIS STUDY investigate the efficacy of $\beta$-sitosterol $\left(10^{-3,} 10^{-5}\right.$ and $10^{-7}$ molar $)$ or gibberellic acid $(100 \mathrm{ppm})$ on alleviating harmful effects of temperature stress $\left(10^{\circ} \mathrm{C}\right.$ and $\left.45^{\circ} \mathrm{C}\right)$ on three cultivars of Lycopersicum esculentum Mill., mainly Fayrouz, Aziza and N23-48 to the purpose the activities of some antioxidant enzymes, protein patterns and DNA finger print in order to focus on the role of $\beta$-sitosterol or gibberellic acid for enhancing plant tolerance against temperature stress. It was found that, temperature stress $\left(10^{\circ} \mathrm{C}\right.$ and $\left.45^{\circ} \mathrm{C}\right)$ decreased the activities of catalase and peroxidase, while $\beta$-sitosterol $\left(10^{-3}, 10^{-5}\right.$ and $10^{-7}$ molar) or gibberellic acid (100ppm) enhanced these enzymes activity. The electrophoresis studies showed that some new protein bands and DNA finger print were observed probably to increase plant tolerance against temperature stress. These results give a positive indication of the use of $\beta$-sitosterol specially $10^{-5}$ molar or gibberellic acid in field application to ameliorate the toxic effects of temperature on tomato plants.
\end{abstract}

Keywords: Tomato, Temperature stress, Sitosterol, Gibberellic acid, Enzymes activity, Protein patterns, DNA finger print.

\section{Introduction:}

During the normal processes of growth and development, plants are subjected to different types of stress, such as drought, heat, ultraviolet light, air pollution, and pathogen attack .Most plants suffer from both physiological and biochemical damage by exposure to temperatures; higher or lower than optimal for growth. The results of these injuries, which are reflected in most metabolic processes, may be reduced growth capacity of the crops and therefore lower commercial yield (Rivero et al., 2001).

Plants response to temperature stress by change their morphology, anatomy, physiology, biochemical and genetic responses (Camejo et al., 2005; Snider et al., 2010; Chen et al., 2012 and Min et al., 2014). It interrupts the scavenging of ROS by antioxidant system (enzymatic and nonenzymatic) leading to rise of oxidative stress that led to destruction of proteins, cell membranes and DNA (Abdalla, 2011).

The temperature stress causes a decrease in normal protein synthesis accompanied by an accelerated synthesis of new proteins known as heat shock proteins (HSPs). This response of plants is observed when they are exposed to temperatures at least $5^{\circ} \mathrm{C}$ above their optimal growing temperature. In addition to physiological indicators/markers of heat tolerance, molecular markers are also promising to help tomato screening and breeding phenomena aimed at improving its heat tolerance. The role played by phytohormone signaling in the modulation of DNA repair gene and the resulting effects on plant adaptation to genotoxic stress are poorly investigated (Dona et al., 2013 ).

Sterols are known to regulate transcriptional and post transcriptional events, which inturn affect lipid synthesis, meiosis, apoptosis, developmental patterning, protein cleavage and protein degradation (Rashad et al., 2009). Gibberellic acid regulates various developmental processes throughout the life cycle of the plant from seed germination through leaf expansion and stem development (Sun \& Gubler, 2004).

"Corresponding author email: samiaharoun@yahoo.com 
The tomato (Lycopersicum esculentum Mill.), is an important vegetable crop widely grown all over the world. Tomato is the number nine crop on the lists of food commodities and widely used as a model crop for source-sink studies and stress (Zhou et al., 2016).

The aim of this study was to investigate the influence of $\beta$-sitosterol or gibberellic acid on alleviate deleterious effect of temperature stress on tomato plants by detecting biochemical and molecular markers.

\section{Materials and Methods}

\section{Experiment preparation}

The three cultivars of Lycopersicom esculentum Mill (Tomato) that used in this study, Fayrouz F1, Aziza F1 and N23-48 F1 were supplied by the Agricultural Research Center, Ministry of Agricultural, Egypt. According to preliminary experiment, the seeds of the three cultivars were soaked for $10 \mathrm{~h}$ in $10^{-3}, 10^{-5}$ and $10^{-7}$ molar $\beta$-sitosterol, 100ppm gibberellic acid $\left(\mathrm{GA}_{3}\right)$ and distilled water (control). Fifty seeds per each (control and treatments) were sown in each germination trays (containing equal amounts of peat moss) at $25 \pm 3^{\circ} \mathrm{C}$. After 28 days from sowing, initial samples were taken. At the same day the seedlings transferring to three growth chambers at temperature $\left(10,25,45 \pm 3^{\circ} \mathrm{C}\right)$. Forty two days from sowing (as the true leaf fully expanded), vegetative samples from each treatment were collected to determine antioxidant enzymes (catalase and peroxidase) and protein patterns was carried out to the three used varieties with treatments have the best results, in addition DNA finger print of N23-48 tomato cultivar leaves was the best responses under the three temperatures.

\section{Estimation of antioxidant enzymes}

The extraction and estimation of the catalase (E.C.1.11.1.6) and peroxidase (E.C.1.11.1.7) was carried out according to Malik \& Singh (1980).

\section{Protein patterns}

SDS-polyacrylamide gel electrophoresis was performed in $12 \%$ acrylamide slab gels following the system of Laemmli (1970) to identify their protein profiles.

\section{Identification of DNA finger print by RAPD-PCR technique}

Genomic DNA was extracted from leaves of
N23-48 cultivar according to Junhans \& Metzlatt (1990) protocol.

\section{Polymerase chain reaction (PCR) conditions and analysis \\ Reaction of RAPD-PCR was performed} according to Williams et al. (1990) using 3 type of 10-mer random primers: (OPA-12 TCGGCGATAG, RAPD5 TTCGACCCAG and RAPD6 AAAGCTGCGG). The PCR reaction was performed in a final volume of $25 \mu \mathrm{l}$ containing: $5 \mu \mathrm{l} 5 \times$ PCR buffer, $2.5 \mu \mathrm{l}$ primer, $3 \mu \mathrm{l} \mathrm{DNA}, 0.5 \mu \mathrm{l}$ Taq polymerase and $14 \mu \mathrm{l}$ sterile distilled water. The PCR was performed with the cycle program of denaturation (one cycle) $94^{\circ} \mathrm{C}$ for $5 \mathrm{~min}, 40$ cycles 1 min. at $94^{\circ} \mathrm{C}, 30 \mathrm{sec}$. at $36^{\circ} \mathrm{C}, 1 \mathrm{~min}$. at $72^{\circ} \mathrm{C}$ and with a final extention of $5 \mathrm{~min}$. at $72^{\circ} \mathrm{C}$. The PCR products were detected on $1 \%$ agarose gel using ethidium bromide and visualized by gel documentation system (GDS).

\section{Data analysis}

The full data of the differently treated groups were statistically analysed and comparison among means was carried out by computer programming method (statgraphic- vers-4-2- Display ANOVA), as described by Scedecore \& Cochran (1982).

\section{Analysis of gel electrophoresis}

Variation in SDS-PAGE and RAPD-PCR bands were analyzed using computer program Gel Analyzer 3.

\section{Results and Discussion}

\section{Changes in antioxidant enzymes}

Data in Tables 1 and 2 showed that, the effect of different concentrations of $\beta$-sitosterol $\left(10^{-3}, 10^{-5}\right.$ and $10^{-7}$ molar $)$ and $\mathrm{GA}_{3}(100 \mathrm{ppm})$ with or without temperature stress $\left(10^{\circ} \mathrm{C}\right.$ and $\left.45^{\circ} \mathrm{C}\right)$ on activities of enzymes catalase and peroxidase, cleared a general significant increase in the used tomato cultivars, compared with untreated plants, during the two stages. However, during vegetative stage as shown in Table 2 of tomato cultivars, a decrease in activities of catalase and peroxidase under temperature stress at $10^{\circ} \mathrm{C}$ and $45^{\circ} \mathrm{C}$ as compared with $25^{\circ} \mathrm{C}$, was detected.

In accordance with these results, there is a direct link between reactive oxygen species (ROS) scavenging and plant stress tolerance under temperature extremes (Suzuki \& Mittler, 2006). Thus, the improvement of temperature stress 
tolerance is often related to enhanced activities of enzymes involved in antioxidant systems of plants. Plants exposed to extreme temperatures use several non-enzymatic and enzymatic antioxidants to cope with the harmful effects of oxidative stress; higher activities of antioxidant defense enzymes are correlated with higher stress tolerance. Different plant studies have revealed that enhancing antioxidant defense confers stress tolerance to either high temperature (HT) or low temperature (LT) stress (Huang \& Guo, 2005 and Almeselmani et al., 2006).

TABLE 1. Effect of the different concentrations of $\beta$-sitosterol or gibberellic acid on different antioxidant enzyme activities ( $\Delta$ absorbance unit $\mathrm{mg} / \mathrm{min} / \mathrm{g} \mathrm{F}$.W) of the three tomato cultivars shoot at initial stage.

\begin{tabular}{|c|c|c|c|}
\hline \multirow{2}{*}{ Cultivars } & \multirow{2}{*}{ Preatment } & \multicolumn{2}{|c|}{ Antioxidant enzyme } \\
\hline & & Catalase & Peroxidase \\
\hline \multirow{5}{*}{ Fayrouz } & Control & 12.26 & 3.06 \\
\hline & $\begin{array}{l}\text { Gibberelins } \\
(100 \mathrm{ppm})\end{array}$ & $14.28 *$ & $4.02 *$ \\
\hline & $\begin{array}{c}\text { Sitosterol } \\
\left(10^{-3} \text { molar }\right)\end{array}$ & *13.73 & $3.45^{*}$ \\
\hline & $\begin{array}{l}\text { Sitosterol } \\
\left(10^{-5} \text { molar }\right)\end{array}$ & $15.19^{*}$ & $4.51 *$ \\
\hline & $\begin{array}{c}\text { Sitosterol } \\
\left(10^{-7} \text { molar }\right)\end{array}$ & $14.05^{*}$ & $3.99 *$ \\
\hline \multirow{5}{*}{ Aziza } & Control & 12.98 & 3.13 \\
\hline & $\begin{array}{l}\text { Gibberelins } \\
(100 \mathrm{ppm})\end{array}$ & $13.65^{*}$ & $3.85^{*}$ \\
\hline & $\begin{array}{c}\text { Sitosterol } \\
\left(10^{-3} \text { molar }\right)\end{array}$ & $13.77^{*}$ & $4.02 *$ \\
\hline & $\begin{array}{l}\text { Sitosterol } \\
\left(10^{-5} \text { molar }\right)\end{array}$ & $14.87 *$ & $4.35^{*}$ \\
\hline & $\begin{array}{l}\text { Sitosterol } \\
\left(10^{-7} \text { molar }\right)\end{array}$ & $13.93 *$ & $4.25^{*}$ \\
\hline \multirow{5}{*}{ N23-48 } & Control & 13.61 & 3.34 \\
\hline & $\begin{array}{l}\text { Gibberelins } \\
(100 \mathrm{ppm})\end{array}$ & $14.58 *$ & $3.84 *$ \\
\hline & $\begin{array}{c}\text { Sitosterol } \\
\left(10^{-3} \text { molar }\right)\end{array}$ & $14.83^{*}$ & $3.92 *$ \\
\hline & $\begin{array}{l}\text { Sitosterol } \\
\left(10^{-5} \text { molar }\right)\end{array}$ & $15.4^{*}$ & $4.66^{*}$ \\
\hline & $\begin{array}{l}\text { Sitosterol } \\
\left(10^{-7} \text { molar }\right)\end{array}$ & $15.21^{*}$ & $4.16^{*}$ \\
\hline
\end{tabular}

*= Significant increase or decrease at 0.05 LSD. 
TABLE 2. Effect of the different concentrations of $\beta$-sitosterol or gibberellic acid on different antioxidant enzyme activities $(\Delta$ absorbance unit $\mathrm{mg} / \mathrm{min} / \mathrm{g} \mathrm{F}$.W) of the three tomato cultivars shoot at vegetative stage.

\begin{tabular}{|c|c|c|c|c|c|c|c|}
\hline \multirow{2}{*}{ Temperatur } & \multirow[t]{2}{*}{ Cultivars } & \multicolumn{2}{|c|}{ Fayrouz } & \multicolumn{2}{|c|}{ Aziza } & \multicolumn{2}{|c|}{$\mathrm{N} 23-48$} \\
\hline & & Catalase & Peroxidase & Catalase & Peroxidase & Catalase & Peroxidase \\
\hline \multirow{5}{*}{$25^{\circ} \mathrm{C}$} & Control & 16.52 & 4.89 & 15.61 & 5.32 & 17.06 & 4.79 \\
\hline & $\begin{array}{c}\mathrm{GA}_{3} \\
(100 \mathrm{ppm})\end{array}$ & $18.76^{*}$ & $6.12 *$ & $15.93 *$ & $5.81 *$ & $17.41^{*}$ & $5.07 *$ \\
\hline & $\begin{array}{c}\text { Sitosterol } \\
\left(10^{-3} \text { molar }\right)\end{array}$ & *16.86 & $5.33 *$ & $16.71 *$ & $6.10^{*}$ & $18.08^{*}$ & $5.48 *$ \\
\hline & $\begin{array}{l}\text { Sitosterol } \\
\left(10^{-5} \text { molar }\right)\end{array}$ & $19.15^{*}$ & $6.28 *$ & $18.26^{*}$ & $6.76^{*}$ & $19.86^{*}$ & $6.13 *$ \\
\hline & $\begin{array}{c}\text { Sitosterol } \\
\left(10^{-7} \text { molar }\right)\end{array}$ & $17.65^{*}$ & $5.71 *$ & $17.90 *$ & $6.59 *$ & $19.33^{*}$ & $5.89 *$ \\
\hline \multirow{5}{*}{$10^{\circ} \mathrm{C}$} & Control & 13.95 & 4.12 & 14.87 & 3.75 & 13.16 & 3.81 \\
\hline & $\begin{array}{c}\mathrm{GA}_{3} \\
(100 \mathrm{ppm})\end{array}$ & $14.89 *$ & $4.78 *$ & $16.93 *$ & $4.66^{*}$ & $13.36^{*}$ & 4.16 \\
\hline & $\begin{array}{c}\text { Sitosterol } \\
\left(10^{-3} \text { molar }\right)\end{array}$ & $14.12 *$ & $4.42 *$ & $15.88^{*}$ & $4.37^{*}$ & $15.09^{*}$ & $4.80 *$ \\
\hline & $\begin{array}{c}\text { Sitosterol } \\
\left(10^{-5} \text { molar }\right)\end{array}$ & $16.09^{*}$ & $5.27 *$ & $17.31 *$ & $4.91 *$ & $15.22 *$ & $4.94 *$ \\
\hline & $\begin{array}{c}\text { Sitosterol } \\
\left(10^{-7} \text { molar }\right)\end{array}$ & $15.81^{*}$ & $5.07 *$ & $15.23 *$ & $4.09 *$ & $14.21 *$ & $4.57 *$ \\
\hline \multirow{5}{*}{$45^{\circ} \mathrm{C}$} & Control & 15.58 & 4.39 & 14.16 & 2.98 & 13.65 & 3.99 \\
\hline & $\begin{array}{c}\mathrm{GA}_{3} \\
(100 \mathrm{ppm})\end{array}$ & $17.63^{*}$ & $5.59 *$ & $16.02 *$ & $4.67 *$ & $14.98^{*}$ & $4.36^{*}$ \\
\hline & $\begin{array}{c}\text { Sitosterol } \\
\left(10^{-3} \text { molar }\right)\end{array}$ & $16.56^{*}$ & $5.23 *$ & $15.43^{*}$ & $4.23 *$ & $16.62 *$ & $5.63 *$ \\
\hline & $\begin{array}{c}\text { Sitosterol } \\
\left(10^{-5} \text { molar }\right)\end{array}$ & $17.93 *$ & $5.75^{*}$ & $17.34^{*}$ & $5.07 *$ & $16.77^{*}$ & $5.21^{*}$ \\
\hline & $\begin{array}{c}\text { Sitosterol } \\
\left(10^{-7} \text { molar }\right)\end{array}$ & $15.87 *$ & $4.78 *$ & $17.05^{*}$ & $4.96^{*}$ & $15.53^{*}$ & $5.31 *$ \\
\hline
\end{tabular}

*= Significant increase or decrease at 0.05 LSD.

Hasanuzzaman et al. (2013) reported that, the cellular changes induced by either high temperature or low temperature includes responses those lead to the excess accumulation of toxic compounds, especially reactive oxygen species (ROS). The end result of ROS accumulation is oxidative stress (Mittler, 2002 and Suzuki \& Mittler, 2006). There are numerous plant studies which indicate the tolerance to temperature stress in plants is positively correlated with an increase in antioxidants (Hasanuzzaman et al., 2012 and Babu \& Devraj, 2008).
The perusal of the recorded data in this study are in record with the results of Djanaguiraman et al. (2010) who observed that high temperature stress decreased antioxidant enzyme activities and increased oxidant production in sorghum. In their study, SOD, CAT and POX activities were decreased in heat stress $(22,15$ and $25 \%$ lower than control plants) and the greater inhibition of all antioxidant enzymes in heat-stressed plants relative to control plants indicates greater inactivation of all antioxidant enzymes by heat stress. The early effects of thermal stress comprise of structural 
alterations in chloroplast protein complexes and reduced activity of enzymes (Ahmad et al., 2010).

In this study, gibberellic acid treatment caused a general significant increase in activities of catalase and peroxidase in both stages of the used tomato cultivars. Gibberellic acid $\left(\mathrm{GA}_{3}\right)$ that primarily affect cell enlargement and growth must also coordinately interact with ABA under stress and possibly other stress metabolites, including antioxidants and ROS scavengers (Achard et al., 2006). As a result of ROS production, plant cell has to activate the antioxidant defense system including enzymatic antioxidant to scavenge ROS (Sairam et al., 2002).

It has been found in this investigation that, during the two stages (initial and vegetative) of tomato cultivars, catalase and peroxidase, significantly increased in response to the different pretreatment of $\beta$-sitosterol in relation to control values. In this respect, there are reports of further beneficial effects of phytosterols, alone and in combination with other naturally occurring compounds as having possible anti-oxidation activities (Van et al., 2000).

Similarly, it has been observed that BRs (brassinosteroids) application caused an increase in CAT activity in both susceptible and resistant varieties of sorghum seedlings under osmotic stress (Vardhini \& Rao, 2003). Furthermore, the activities of antioxidant enzymes such as SOD, APX, CAT, and guaiacol POD were significant in EBL (24-epibrassinolide) treated tomato plants under heat stress (Dhaubhadel et al., 1999) and (Mazorra \& Núñez, 2000) reported that, EBL and MH5 (BR analogue) stimulated CAT activity in tomato leaf discs under heat stress. Nevertheless, although BRs and ROS are thought to act as secondary messengers for the induction of antioxidant defences in stressed plants, the relationship between BRs and ROS in stress-signal transduction remains unclear (Ogweno et al., 2008).

\section{Change in protein banding patterns of leaves}

The best responses while studying the protein patterns of the three tomato cultivars were the ones treated with $100 \mathrm{ppm}$ gibberellic acid or $10^{-5}$ molar $\beta$ - sitosterol under the three temperature $\left(25^{\circ} \mathrm{C}\right.$, $10^{\circ} \mathrm{C}$ and $45^{\circ} \mathrm{C}$ ), and for that reason they were the ones discussed in this study.

Treatment of Fayrouz cultivar with 100ppm $\mathrm{GA}_{3}$ (plate1 and Table 3a) led to express 9 protein bands and appearance of new bands at 31.22, 28.96, 27.63 and $23.16 \mathrm{kDa}$ and by $10^{-5}$ molar $\beta$ - sitosterol, expression of 11 bands with new protein bands (at $50.80,36.29,31.22,28.96$ and 27.63) and absence band at $76.85 \mathrm{kDa}$ with the two treatments in response to control sample grown under $25^{\circ} \mathrm{C}$.

By growing plants under $10^{\circ} \mathrm{C}$, no changes were detected in protein patterns between control and treatments with $\mathrm{GA}_{3}$ and $\beta$-sitosterol excepts new band expressed at $49.86 \mathrm{kDa}$ in response to treatment by $10^{-5}$ molar $\beta$-sitosterol, total number of bands to both control and 100ppm $\mathrm{GA}_{3}$ were 12 bands but $\beta$-sitosterol recorded 13 bands. Concerning treatment at $45^{\circ} \mathrm{C}$, increased the protein bands after treatment by $100 \mathrm{ppm} \mathrm{GA}_{3}$ to 13 bands and expression of new protein bands (at 90.60, $50.80,48.35,41.01,31.22,28.96$ and $27.63 \mathrm{kDa})$ and by treatment with $\beta$-sitosterol induced increase in the bands to 11 bands and appearance of five new bands (at 50.80, 48.35, 31.22, 28.96 and $27.63 \mathrm{kDa}$ ) as composed to the control bands ( 7 bands).

Aziza cultivar leaves exhibited the same bands as in control in response to all treatments under $25^{\circ} \mathrm{C}$ (Plate 1 and Table $3 \mathrm{~b}$ ). At $10^{\circ} \mathrm{C}$, treatment plants with $10^{-5}$ molar $\beta$ - sitosterol or $\mathrm{GA}_{3}$ induced decrease the bands to 11 bands as compared with the control which have 13 bands with two unique bands (at 199.50 and 95.26). Application of high temperature $\left(45^{\circ} \mathrm{C}\right)$ either alone or plus treatments with $100 \mathrm{ppm}$ gibberellic acid or $10^{-5}$ molar $\beta$ sitosterol led to express new protein band, at 83.13kDa.

Concerning N23-48 cultivar grown under $25^{\circ} \mathrm{C}$ (Plate 1 and Table 3c), the gel indicated that the total number of bands in each treatments 6 bands. Treatment of $\mathrm{N} 23-48$ cultivar with $100 \mathrm{ppm} \mathrm{GA}_{3}$ and grown under $10^{\circ} \mathrm{C}$ led to express of 9 protein bands and appearance of three new bands (at 103.32, 46.60 and $34.10 \mathrm{kDa}$ ). Meanwhile application of $10^{-5}$ molar $\beta$-sitosterol with $10^{\circ} \mathrm{C}$ led to separation of 10 protein bands with appearance of 4 new bands (at 151.64 unique, $103.32,46.60$ and $34.16 \mathrm{kDa}$ ) as compared to the control. On the other hand, under $45^{\circ} \mathrm{C}$, treatment of tomato with gibberellic acid expressed 7 bands, with appearance of one new band (at $34.10 \mathrm{kDa}$ ), whereas application with $\beta$-sitosterol led to separation of 9 protein bands with appearance of three new bands (at 66.14, 46.60 and 34.10) and absence of one band in both treatments (GA and $\beta$-sitosterol) at $81.21 \mathrm{kDa}$ in relation to control. 
TABLE 3a. Effect of the different concentrations of $\beta$-sitosterol or gibberellic acid on protein banding patterns of Fayrouz cultivar leaves.

\begin{tabular}{|c|c|c|c|c|c|c|c|c|c|c|c|c|}
\hline \multirow[b]{3}{*}{ Polymorphism } & \multirow[b]{3}{*}{ Frequency } & \multicolumn{9}{|c|}{ Treatments } & \multirow[b]{3}{*}{$\begin{array}{l}\text { M.W } \\
\text { (kD) }\end{array}$} & \multirow[b]{3}{*}{$\mathbf{R F}$} \\
\hline & & \multicolumn{3}{|c|}{$45^{\circ} \mathrm{C}$} & \multicolumn{3}{|c|}{$10^{\circ} \mathrm{C}$} & \multicolumn{3}{|c|}{$25^{\circ} \mathrm{C}$} & & \\
\hline & & $\begin{array}{c}\text { Sito- } \\
10^{-5} \\
\text { molar }\end{array}$ & $\begin{array}{c}\mathbf{G A}_{3} \\
100 \\
\text { ppm }\end{array}$ & Control & $\begin{array}{l}\text { Sito- } \\
10^{-5} \\
\text { molar }\end{array}$ & $\begin{array}{c}\mathrm{GA}_{3} \\
100 \\
\text { ppm }\end{array}$ & Control & $\begin{array}{l}\text { Sito- } \\
10^{-5} \\
\text { molar }\end{array}$ & $\begin{array}{l}\mathbf{G A}_{3} \\
100 \\
\mathrm{ppm}\end{array}$ & Control & & \\
\hline Monomorphic & 1 & + & + & + & + & + & + & + & + & + & 161.97 & 0.139 \\
\hline Polymorphic & 0.333 & - & - & - & + & + & + & - & - & - & 105.57 & 0.321 \\
\hline Monomorphic & 1 & + & + & + & + & + & + & + & + & + & 93.64 & 0.372 \\
\hline Unique & 0.111 & - & + & - & - & - & - & - & - & - & 90.60 & 0.386 \\
\hline Polymorphic & 0.556 & - & - & + & + & + & + & - & - & + & 76.85 & 0.456 \\
\hline Monomorphic & 1 & + & + & + & + & + & + & + & + & + & 64.58 & 0.530 \\
\hline Polymorphic & 0.333 & + & + & - & - & - & - & + & - & - & 50.80 & 0.632 \\
\hline Unique & 0.111 & - & - & - & + & - & - & - & - & - & 49.86 & 0.640 \\
\hline Polymorphic & 0.222 & + & + & - & - & - & - & - & - & - & 48.35 & 0.653 \\
\hline Monomorphic & 1 & + & + & + & + & + & + & + & + & + & 45.27 & 0.681 \\
\hline Polymorphic & 0.333 & - & + & - & + & + & + & - & - & - & 41.01 & 0.723 \\
\hline Unique & 0.111 & - & - & - & - & - & - & + & - & - & 36.29 & 0.775 \\
\hline Polymorphic & 0.667 & + & + & - & + & + & + & + & + & - & 31.22 & 0.839 \\
\hline Polymorphic & 0.667 & + & + & - & + & + & + & + & + & - & 28.96 & 0.871 \\
\hline Polymorphic & 0.667 & + & + & - & + & + & + & + & + & - & 27.63 & 0.891 \\
\hline Monomorphic & 1 & + & + & + & + & + & + & + & + & + & 24.50 & 0.942 \\
\hline Unique & 0.111 & - & - & - & - & - & - & - & + & - & 23.16 & 0.966 \\
\hline \multirow[t]{2}{*}{ Polymorphic } & 0.889 & + & + & + & + & + & + & + & - & + & 23.00 & 0.969 \\
\hline & & 11 & 13 & 7 & 13 & 12 & 12 & 11 & 9 & 7 & \multicolumn{2}{|c|}{ Total bands } \\
\hline
\end{tabular}

Sito- $=\beta$-Sitosterol

From table of present or absent protein bands showed that :

- $\quad$ Total number of bands $=18$

- Monomorphic bands $=5$, polymorphic $=9$, unique $=4$

- $\quad$ Maximum M.W. =161.97, Minimum M.W. =23.00

- $\quad$ Polymorphism $(\%)=78.947$

- $\quad$ Mean of band frequency $=0.497$ 
TABLE 3b. Effect of the different concentrations of $\beta$-sitosterol or gibberellic acid on protein banding patterns of Aziza cultivar leaves.

\begin{tabular}{|c|c|c|c|c|c|c|c|c|c|c|c|c|}
\hline \multirow{3}{*}{ Polymorphism } & \multirow{3}{*}{ Frequency } & \multicolumn{9}{|c|}{ Treatments } & \multirow{3}{*}{$\begin{array}{l}\text { M.W } \\
\text { (kD) }\end{array}$} & \multirow{3}{*}{ RF } \\
\hline & & \multicolumn{3}{|c|}{$45^{\circ} \mathrm{C}$} & \multicolumn{3}{|c|}{$10^{\circ} \mathrm{C}$} & \multicolumn{3}{|c|}{$25^{\circ} \mathrm{C}$} & & \\
\hline & & $\begin{array}{c}\text { Sito- } \\
10^{-5} \\
\text { Molar }\end{array}$ & $\begin{array}{l}\mathrm{GA}_{3} \\
100 \\
\mathrm{ppm}\end{array}$ & Control & $\begin{array}{l}\text { Sito- } \\
10^{-5} \\
\text { molar }\end{array}$ & $\begin{array}{l}\mathrm{GA}_{3} \\
100 \\
\mathrm{ppm}\end{array}$ & Control & $\begin{array}{c}\text { Sito- } \\
10^{-5} \\
\text { molar }\end{array}$ & $\begin{array}{l}\mathrm{GA}_{3} \\
100 \\
\mathrm{ppm}\end{array}$ & Control & & \\
\hline Unique & 0.111 & - & - & - & - & - & + & - & - & - & 199.50 & 0.01 \\
\hline Unique & 0.111 & - & - & - & - & - & + & - & - & - & 95.26 & 0.33 \\
\hline Polymorphic & 0.333 & + & + & + & - & - & - & - & - & - & 83.13 & 0.389 \\
\hline Monomorphic & 1 & + & + & + & + & + & + & + & + & + & 73.89 & 0.44 \\
\hline Polymorphic & 0.333 & - & - & - & + & + & + & - & - & - & 65.68 & 0.491 \\
\hline Monomorphic & 1 & + & + & + & + & + & + & + & + & + & 52.01 & 0.592 \\
\hline Monomorphic & 1 & + & + & + & + & + & + & + & + & + & 45.17 & 0.653 \\
\hline Monomorphic & 1 & + & + & + & + & + & + & + & + & + & 41.76 & 0.687 \\
\hline Monomorphic & 1 & + & + & + & + & + & + & + & + & + & 33.15 & 0.787 \\
\hline Monomorphic & 1 & + & + & + & + & + & + & + & + & + & 30.36 & 0.825 \\
\hline Polymorphic & 0.333 & - & - & - & + & + & + & - & - & - & 26.99 & 0.876 \\
\hline Polymorphic & 0.333 & - & - & - & + & + & + & - & - & - & 24.89 & 0.911 \\
\hline Monomorphic & 1 & + & + & + & + & + & + & + & + & + & 21.87 & 0.967 \\
\hline Monomorphic & 1 & + & + & + & + & + & + & + & + & + & 21.08 & 0.983 \\
\hline & & 9 & 9 & 9 & 11 & 11 & 13 & 8 & 8 & 8 & Total b & ands \\
\hline
\end{tabular}

Sito- $=\beta$-Sitosterol

From table of present or absent protein bands showed that :

- $\quad$ Total number of bands $=14$

- $\quad$ Monomorphic bands $=8$, polymorphic $=4$, unique $=2$

- $\quad$ Maximum M.W. =199.50, Minimum M.W. =21.08

- $\quad$ Polymorphism $(\%)=50 \%$

- $\quad$ Mean of band frequency $=0.659$ 
TABLE 3c. Effect of the different concentrations of $\beta$-sitosterol or gibberellic acid on protein banding patterns of N23-48 cultivar leaves.

\begin{tabular}{|c|c|c|c|c|c|c|c|c|c|c|c|c|}
\hline \multirow{3}{*}{ Polymorphism } & \multirow{3}{*}{ Frequency } & \multicolumn{9}{|c|}{ Treatments } & \multirow{3}{*}{$\begin{array}{c}\text { M.W } \\
(\mathbf{k D})\end{array}$} & \multirow{3}{*}{ RF } \\
\hline & & \multicolumn{3}{|c|}{$45^{\circ} \mathrm{C}$} & \multicolumn{3}{|c|}{$10^{\circ} \mathrm{C}$} & \multicolumn{3}{|c|}{$25^{\circ} \mathrm{C}$} & & \\
\hline & & $\begin{array}{l}\text { Sito- } \\
10^{-5} \\
\text { molar }\end{array}$ & $\begin{array}{l}\mathrm{GA}_{3} \\
100 \\
\text { ppm }\end{array}$ & Control & $\begin{array}{c}\text { Sito- } \\
10^{-5} \\
\text { molar }\end{array}$ & $\begin{array}{c}\mathrm{GA}_{3} \\
100 \\
\text { ppm }\end{array}$ & Control & $\begin{array}{c}\text { Sito- } \\
10^{-5} \\
\text { molar }\end{array}$ & $\begin{array}{c}\mathrm{GA}_{3} \\
100 \\
\mathrm{ppm}\end{array}$ & Control & & \\
\hline Unique & 0.111 & - & - & - & + & - & - & - & - & - & 151.64 & 0.102 \\
\hline Polymorphic & 0.222 & - & - & - & + & + & - & - & - & - & 103.32 & 0.274 \\
\hline Polymorphic & 0.333 & - & - & - & + & + & + & - & - & - & 91.19 & 0.33 \\
\hline Unique & 0.111 & - & - & + & - & - & - & - & - & - & 81.21 & 0.382 \\
\hline Polymorphic & 0.444 & + & - & - & + & + & + & - & - & - & 66.14 & 0.474 \\
\hline Polymorphic & 0.667 & + & + & + & - & - & - & + & + & + & 54.11 & 0.564 \\
\hline Polymorphic & 0.667 & + & + & + & - & - & - & + & + & + & 51.18 & 0.589 \\
\hline Polymorphic & 0.333 & + & - & - & + & + & - & - & - & - & 46.60 & 0.631 \\
\hline Polymorphic & 0.444 & + & + & - & + & + & - & - & - & - & 34.10 & 0.771 \\
\hline Monomorphic & 1 & + & + & + & + & + & + & + & + & + & 30.30 & 0.824 \\
\hline Monomorphic & 1 & + & + & + & + & + & + & + & + & + & 28.15 & 0.857 \\
\hline Monomorphic & 1 & + & + & + & + & + & + & + & + & + & 21.60 & 0.974 \\
\hline Monomorphic & 1 & + & + & + & + & + & + & + & + & + & 21.02 & 0.988 \\
\hline & & 9 & 7 & 7 & 10 & 9 & 6 & 6 & 6 & 6 & Total b & ands \\
\hline
\end{tabular}

Sito- $=\beta$-Sitosterol

From table of present or absent protein bands showed that :

- $\quad$ Total number of bands $=13$

- $\quad$ Monomorphic bands $=4$, polymorphic $=7$, unique $=2$

- $\quad$ Maximum M.W. $=151.64$, Minimum M.W. $=21.02$

- $\quad$ Polymorphism $(\%)=69.23$

- $\quad$ Mean of band frequency $=0.564$ 


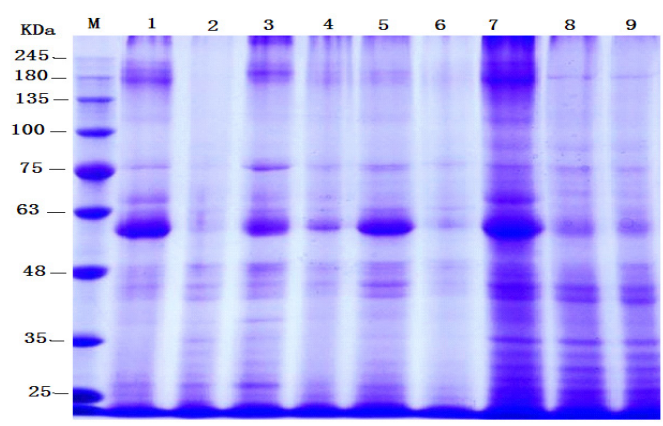

(Faurouz)

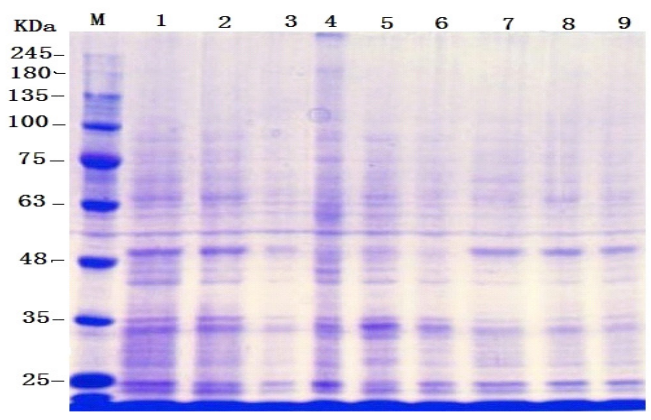

(Aziza)

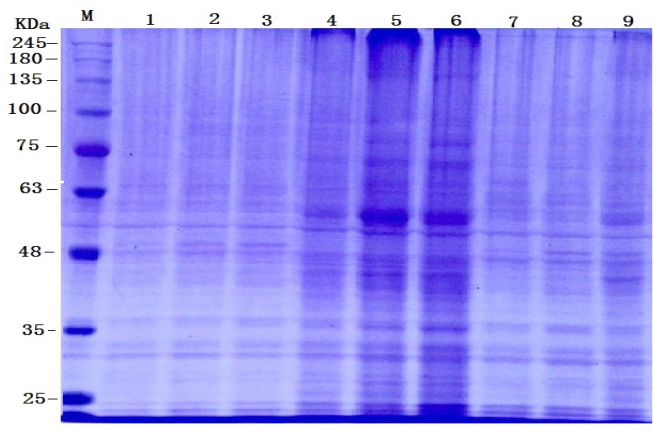

(N23-48)

Plate 1. Effect of the different concentrations of $\beta$-sitosterol or gibberellic acid on the protein banding patterns of three tomato cultivars, $\mathbf{M}=$ marker $\left(1=\right.$ control $2=\mathbf{G A}_{3}$ $3=10-5$ sito- at $\left.25^{\circ} \mathrm{C}\right),\left(4=\right.$ control $5=\mathrm{GA}_{3}$ $6=10-5$ sito - at $\left.10^{\circ} \mathrm{C}\right)$ and $\left(7=\right.$ control $8=\mathrm{GA}_{3}$ $9=10-5$ sito - at $\left.25^{\circ} \mathrm{C}\right)$.

These results are in agreement with Yang et al. (2006) who found that the pattern of gene expression changed by heat stress, which is the way to improve plant-heat tolerance.

El-Enany et al. (2013) recorded the presence of fifteen protein bands in Lupinusalbus leaves grown under high temperature $\left(42^{\circ} \mathrm{C}\right)$ at different time periods with the appearance of few new bands due to heat stress and presence of heat shock protein.
Mahla et al. (2011) stated that, all organisms respond to elevated temperature with the production of a defined set of proteins called heat shocked proteins. These heat shocked proteins (HSPs) protect the cells from detrimental effect of high temperature, and that accumulation of HSPs, leads to increase in thermotolerance. A large number of studies reveal a positive correlation between inductions of HSPs and acquisition of thermal tolerance (Bhattacharjee \& Mukherjee, 2006). In wheat seedlings, Joshi et al. (1997) linked the acquired thermo-tolerance with $26 \mathrm{kDa}$ plastid localized heat shocked protein. The results are also in accordance with the findings of Mahmoud \& Mohamed (2007) who observed the production of HSPs bands of MW $17 \mathrm{kDa}$ and $103.7 \mathrm{kDa}$ in wheat seedlings exposed to differential temperature stress. Ouebbou \& Paulsen (1999) found a new set of heat shocked proteins $(17-80 \mathrm{kDa})$ induced within $4 \mathrm{~h}$ in wheat when the temperature of incubation was raised to $37^{\circ} \mathrm{C}$.

Dhaubhadel et al. (1999) in a study, suggested that increased stress resistance of 24-epibrassinolide (EBR)-treated seedlings may be due, at least in part, to the increased accumulation of the various HSPs in these seedlings. They suggested that, the higher accumulation of HSPs transcripts during heat stress in EBR-treated seedlings, in addition to higher accumulation of HSPs at later time points, clearly indicates that the treated seedlings are primed towards responding more efficiently to heat stress than are untreated seedlings. In addition, the differences in HSPs accumulation between treated and untreated seedlings were observed several days before the symptoms of damage began to appear.

In current study, Fayrouz and N23-48 tomato cultivars gave the best response by treatments (temperatures and either 100ppm gibberellic acid or $10^{-5}$ molar $\beta$-sitosterol) rather than Aziza cultivar which showed nearly no response. Thus, in Fayrouz and N23-48 cultivars, protein band at 76.85 and $81.21 \mathrm{kDa}$, respectively generally disappeared by all used treatments and these bands could be considered as a negative specific marker for heat stress shock (El- Enany et al. , 2013).

On the other hand, certain new bands expressed generally ranging from 31.22 to $23.00 \mathrm{kDa}$ in case of Fayrouz cultivar and from 46.60 to $34.10 \mathrm{kDa}$ in case of N23-48. In this concern, the appearance of new bands in heat treated plants should be attributed to expression of heat stress genes. 
These results were in harmony with the work of Yamaguchi et al. (1995) and Cherian \& Ferreira (2010) who reported that the exposure of plants to heat shock treatment lead to the synthesis of new protein bands with small molecular weight which are called heat shock proteins (HSPs). These changes may attribute to the modifications in gene expression due to heat stress.

In this respect, phytohormones are essential for the ability of plants to adapt to abiotic stresses by mediating a wide range of adaptive responses (Peleg \& Blumwald, 2011). They often rapidly alter gene expression by inducing or preventing the degradation of transcriptional regulators via the ubiquitin proteasome system (Santner \& Estelle, 2010).

Molecular genetic polymorphism by RAPD-PCR

Although the three tomato cultivars were subjected to the same treatments (temperatures and either $100 \mathrm{ppm}$ gibberellic acid or $10^{-3}, 10^{-5}$ and $10^{-7}$ molar $\beta$-sitosterol), only N23-48 tomato cultivar was the most affected especially while being treated with $100 \mathrm{ppm}$ gibberellic acid or $10^{-5}$ molar $\beta$-sitosterol, and that is why this cultivar subjected to these treatments were used while studying the DNA finger print.

Three arbitrary random amplified polymorphic DNA(RAPD) primers (APO-12, RAPD5 and RAPD6) were used to amplify the genotypes of untreated and treated tomato plants subjected to three grades of temperature stress (Plate 2 and Table 4).

A total of 21 amplified DNA fragments ranging in size from 1.9 to $0.35 \mathrm{Kbp}$ were realized using the 3 primers, three monomorphic, 13 polymorphic and 5 unique bands were revealed in N23-48 tomato cultivar for the control as well as the sample treated with different treatments. The polymorphic percentage of the 3 primers (APO-12, RAPD5 and RAPD6) was 80, 100 and $71.429 \%$ successively. The highest number of RAPD bands was detected for primer RAPD5 (9 bands), while the lowest was scored for OPA-12 (5 bands).

RAPD analysis of N23-48 tomato cultivar revealed the induction of 30 and 36 distinctive bands response to gibberellic acid and $\beta$-sitosterol treatment successively of stressed and unstressed plants using the 3 primers as compering 28 bands to untreated. Noteworthy that growth regulators application to both unstressed or variously stressed plants induced the highest number of DNA amplified segments as compared to either control or stressed plants. These criteria can be considered as a positive genetic marker for growth regulators tolerance to stress condition. These results were accommodated with similar studies. In this connection, DNA polymorphisms can become useful markers in general fingerprinting (Kawakami et al., 1999 and Shehata \& EL-Khawas, 2003).

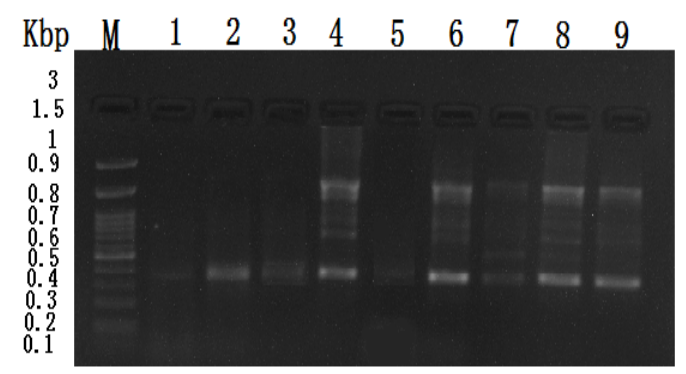

Primer $0 \mathrm{PA}-12$

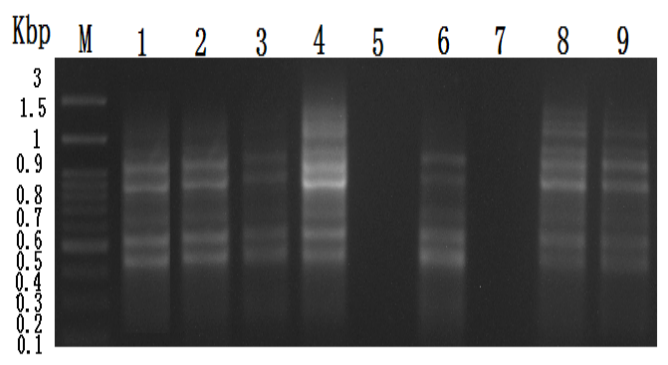

Primer RAPD5

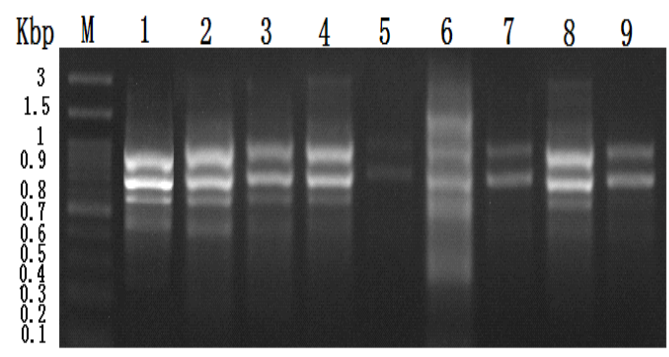

Primer RAPD6

Plate 2. DNA polymorphism of N23-48 tomato cultivar using RAPD primers (OPA12, RAPD5 and RAPD6), $M=$ marker $\left(1=\right.$ control $2=\mathrm{GA}_{3} 3=10-5$ sito- at $25^{\circ} \mathrm{C}$ ), $\left(4=\right.$ control $5=\mathrm{GA}_{3} 6=10-5$ sito- at $\left.10^{\circ} \mathrm{C}\right)$ and ( $7=$ control $8=\mathrm{GA}_{3} 9=10-5$ sito- at $45^{\circ} \mathrm{C}$ ). 


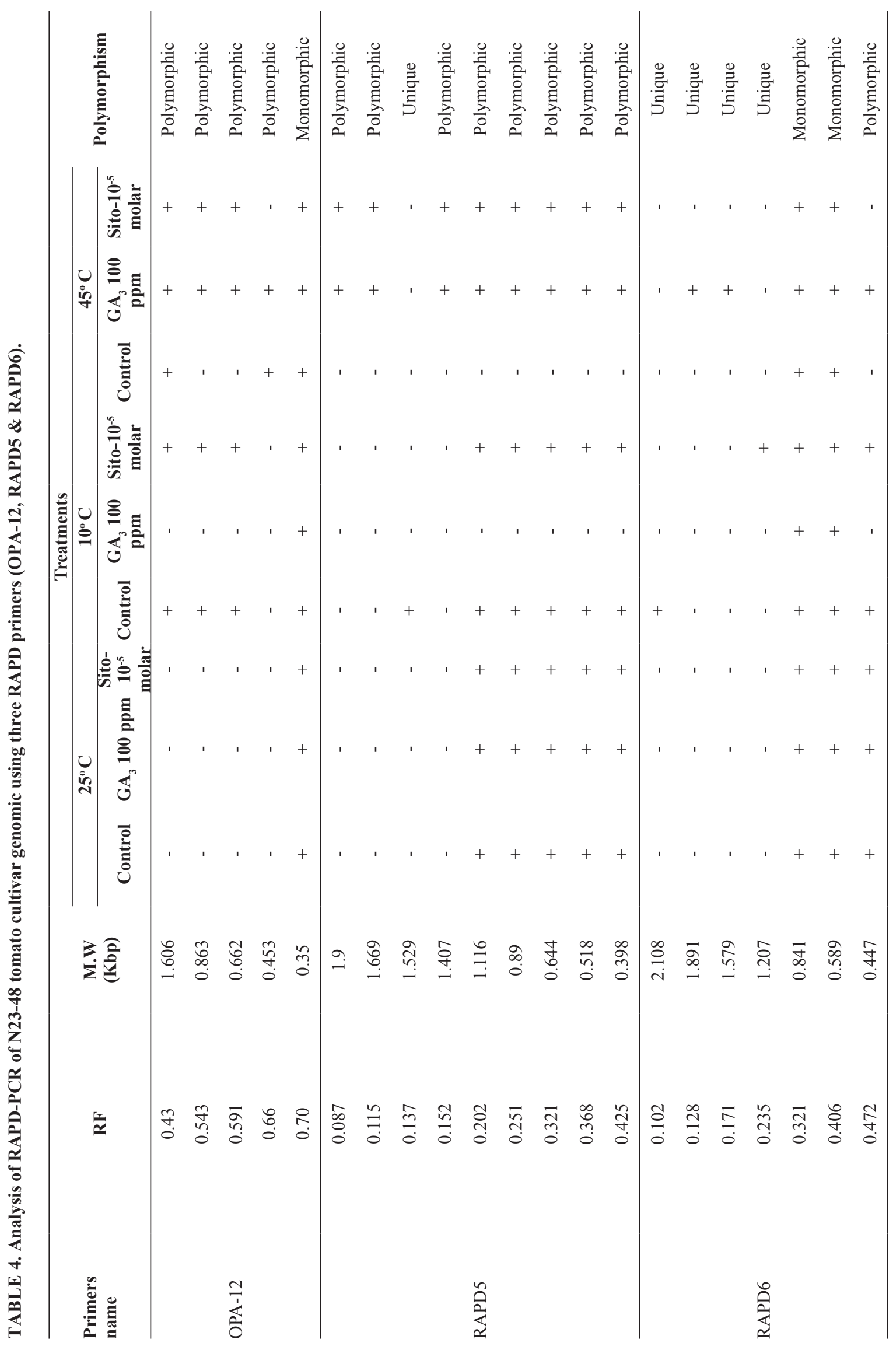


Ganash (2016) stated that, plants sprayed with yeast extract and gibberellic acid showed morphological and/or physiological changes when compared to control samples. These changes might be a result of physiological effect or genetic modifications after using random amplified polymorphic DNA analysis. DNA polymorphisms might be rendered to the loss and/or gain of amplified bands in the treated samples compared with the control. Also, Yang \& Quiros (1993) postulated that quantitative changes could be explained on the basis of alterations of some DNA sequences.

Random Amplified Polymorphic DNA analysis is suitable for genotyping, phylogenetic analysis and molecular selection (Gokturk al., 2003; Atak et al., 2004 and Yuzbasioglu et al., 2006). It has been widely used in the phylogenetic analysis of many plants and a general concordance was demonstrated among the results derived from RAPD and other techniques (Naugzemys et al., 2007). The presence or absence of RAPD bands are used to estimate diversity and in measurement of similarity (Choi et al., 2006 and Wang et al., 2009). Appearance of new bands is usually resulting from different structural changes of DNA (breaks, transpositions, deletion etc.) (Danylchenko \& Sorochinsky, 2005). Hegazi \& Hamideldin (2010) observed that the changes in the DNA bands, where the main changes in the RAPD profiles of the appearance or disappearance of different bands with variation in their intensity. These effects might be due to the structural rearrangements in DNA caused by different types of DNA damages. Khan et al. (2010) reported significant genetic variability in various morphological and physiological traits of wheat under stress conditions.

\section{Conclusion}

It is clear from the previous results that soaking of tomato seeds in $\beta$-sitosterol especially $10^{-5}$ molar or gibberellic acid (100ppm) improves the tolerance of three tomato cultivars; especially N23-48 to temperature stress.

\section{References}

Abdalla, M. (2011) Beneficial effects of diatomite on the growth, the biochemical contents and polymorphic DNA in Lupinusalbus plants grown under water stress. Agric. Biol. J. N. Am. 2(2), 207-220.
Achard, P., Cheng, H., De Grauwe, L., Decat, J., Schoutteten, H., Moritz, T., Van Der Straeten, D., Peng, J. and Harberd, N.P. (2006) Integration of plant responses to environmentally activated phytohormonal signals. Sci. 311, 91-94.

Ahmad, P., Umar, S. and Sharma, S. (2010)Mechanism of free radical scavenging and role of phytohormones in plants under abiotic stresses. In: "Plant Adaptation and Phytoremediation", M. Ashraf, M. Ozturk and M.S.A. Ahmad (Ed.), pp.99-118. Dordrecht; Heidelberg; London; New York, NY: Springer.

Almeselmani, M., Deshmukh, P.S., Sairam, R.K., Kushwaha, S.R. and Singh, T.P. (2006) Protective role of antioxidant enzymes under high temperature stress. Plant Sci. 171, 382-388.

Atak, C., Alikamanoglu, S., Acik, L. and Canbolat., Y. (2004) Induced of plastid mutations in soybean plant (Glycine max. L. Merrill) with gamma radiations and determination with RAPD. Mutat. Res. 556, 35 44.

Babu, N.R. and Devraj, V.R. (2008) High temperature and salt stress response in French bean (Phaseolus vulgaris). Aust. J. Crop Sci. 2, 40-48.

Bhattacharjee, S. and Mukherjee, A.K. (2006) Heat and salinity induced oxidative stress and changes in protein profile in Amaranthus lividus L. Indian. J. Plant Physiol. 11, 41-47.

Camejo, D., Rodrguez, P., Morales, M.A., Dell'Amico, J.M., Torrecillas, A. and Alarcon, J.J. (2005) High temperature effects on photosynthetic activity of two tomato cultivars with different heat susceptibility. $J$. Plant Physiol. 162, 281-289.

Chen, L., Ren, Y., Zhang, Y., Xu, J., Sun, F., Zhang, Z. and Wang, Y. (2012) Genome-wide identification and expression analysis of heat-responsive and novel microRNAs in Populus tomentosa. Gene, 504, 160-165.

Cherian, S. and Ferreira, R.B. (2010) Analysis of Lupinus albus heat-shock granule proteins in response to high temperature stress. Biol. Plantarum, 54(3), 587-591.

Choi, S.H., Kim, M.J., Lee, J.S. and Ryu, K.H. (2006) Genetic diversity and phylogenetic relationships among and within species of oriental cymbidiums based on RAPD analysis. Sci. Hortic. 108, 79-85. 
Danylchenko, O. and Sorochinsk, B. (2005) Use of RAPD assay for the detection of mutation changes in plant DNA induced by UV- B and X-rays BMC. Plant Biol. 5(1), 59.

Dhaubhadel, S., Chaudhary, S., Dobinson, K.F. and Krishna, P. (1999) Treatment with 24-epibrassinolide, a brassinosteroid, increases the basic thermo-tolerance of Brassica napus and tomato seedlings. Plant Mol. Biol. 40, 333-342.

Djanaguiraman, M., Prasad, P.V.V. and Seppanen, M. (2010) Selenium protects sorghum leaves from oxidative damage under high temperature stress by enhancing antioxidant defense system. Plant Physiol. Biochem. 48, 999-1007.

Dona, M., Macovei, A., Fae, M., Carbonera, D. and Balestrazzi, A. (2013) Plant hormone signaling and modulation of DNA repair under stressful conditions. Plant Cell Rep. 32,1043-1052.

El-Enany, M., Mahfouze, S. and El-Dessouky, S. (2013) Gene expression of heat stress on protein and antioxidant enzyme activities of two Lupinus species. J. Appl. Sci. Res. 9(1), 240-247.

Ganash, M.A. (2016) Impact of biostimulant and synthetic hormone gibberellic acid on molecular structure of Solanum melongena L. J. Mole. Biol. Res. 6(1).

Gokturk, R.S., Sumbul, H. and Acik., L. (2003) A new species of Cephalaria Schrader ex Roemer \& Schultes (Dipsacaceae) including a new variety of its from East Anatolia, Turkey. Israel J. Plant Sci. 51, 59-65.

Hasanuzzaman, M., Hossain, M.A., Teixeira da Silva, J.A. and Fujita, M. (2012) Plant response and tolerance to abiotic oxidative stress: Antioxidant defense is a key factor. In: "Crop Stress and its Management: Perspectives and Strategies", Bandi, V., Shanker, A.K., Shanker, C. and Mandapaka, M. (Ed.), pp. 261-315. Springer, The Netherlands.

Hasanuzzaman, M., Nahar, K. and Fujita, M. (2013) Extreme temperature responses, oxidative stress and antioxidant defense in plants. Agri. Biol. Sci. 51, 1024-1032.

Hegazi, A.Z. and Hamideldin, N. (2010) The effect of gamma radiation on enhancement of growth and seed yield of okra (Abelmoschus esculentus L.
Moench) and associated molecular changes. J. Horti Forestry, 2(3), 038-051.

Huang, M. and Guo, Z. (2005) Responses of antioxidant system to chilling stress in two rice cultivars differing in sensitivity. Biol. Plant, 49, 81-89.

Joshi, C.P., Klueva, N.Y., Morrow, K.J. and Nguyen, H.T. (1997) Expression of a unique plastid-localized heat-shock protein is genetically linked to acquired thermotolerance in wheat. Theor. Appl. Genet. 95, 834-841.

Junhans, A. and Metzlat, M. (1990) A simple and rapid method for the preparation of total plant DNA. Biotechniques, 8, 176.

Kawakami, K., Yasuda, J., Kayama, T., Doi, K. and Sokiyaa, T. (1999) Structures of primer-template hybrides in arbitrarily primed polymerase chain reaction. Genetic Analysis: Biomolecular Engineer. $15,5-8$.

Khan, A., Samiullah, S. and Siddique, S. (2010) Genetic variability and correlation among seedling traits of wheat (Triticum aestivum L.) under water stress. Int. J. Agric. Biol. 12(2), 247-250.

Laemmli, U.K. (1970) Cleavage of structural proteins during the assembly of the head of Bacteriophage T4. Nature, 227, 680.

Mahla, R., Madan, S., Munjal, R., Chawla, S., Dua, Y. and Arora, V. (2011) Changes in protein profile, ascorbic acid and chlorophyll stability index of wheat (Triticum aestivum L.) seedlings under heat stress and revival conditions. J. Wheat Res. 3, 18-22.

Mahmoud, H.A.D. and Mohamed, F.I. (2007) Effect of heat stress on chromosomes and protein patterns in six hexaploid wheat varieties. Cell Mole. Biol. 1, 42-49.

Malik, C.P. and Singh, M.B. (1980) "Plant Enzymology and Histoenzymology". Kalyani Publishers, New Delhi, pp. 286.

Mazorra, L.M. and Núñez, M. (2000) Brassinosteroid analogues differentially modify peroxidase activity, superoxide dismutase activity and protein content in tomato seedling. Cultivos Tropicales, 21(4), 29-33.

Min, L., Li, Y., Hu, Q., Zhu, L., Gao, W., Wu, Y., Ding, Y., Liu, S., Yang, X. and Zhang, X. ( 2014) Sugar 
and auxin signalling pathways respond to hightemperature stress during anther development as revealed by transcript profiling analysis in cotton. Plant Physiol. 164, 1293-1308.

Mittler, R. (2002) Oxidative stress, anioxidants and stress tolerance. Trends Plant Sci. 7, 405-410.

Naugzemys, D., Zilinskaite, S., Denkovskij, J., Patamsyte, J., Literskis, J. and Zvingila, D. (2007) RAPD based study of genetic variation and relationships among Lonicera germplasm accessions. Biologia, 53(3), 34-39.

Ogweno, J.O., Song, X.S., Shi, K., Hu, W.H., Mao, W.H., Zhou, Y.H., Yu, J.Q. and Nogués, S. (2008) Brassinosteroids alleviate heat-induced inhibition of photosynthesis by increasing carboxylation efficiency and enhancing antioxidant systems in Lycopersicom esculentum. J. Plant Growth Regul. 27, 49-54.

Ouebbou, H. and Paulsen, G.M. (1999) Recovery of heat-induced heat shock proteins and evidence of the binding of some small molecular weight to the thylakoid membranes in wheat. Rachis, 18, 55-59.

Peleg, Z. and Blumwald, E. (2011) Hormone balance and abiotic stress tolerance in crop plants. Plant Biol. 14, 290-295.

Rashad, E.M., Abd El-Wahed, M.S.A. and Amin, A.A. (2009) Effect of $\beta$-sitosterol and gibberellic acid on leaf angle, growth, flowering and biochemical constituents of marigold (Calendula officinalis L.). J. Agric .Sci .Mans. Univ. 33(11), 21-27.

Rivero, R., Ruiz, J., Garc1'a, P., Lefebre, L., Sa'nchez, E. and Romero, L. (2001) Resistance to cold and heat stress: Accumulation of phenolic compounds in tomato and watermelon plants. Plant Sci. 160, 315-321.

Santner, A. and Estelle, M. (2010) The ubiquitinproteasome system regulates plant hormone signaling. The Plant J. 61, 1029-1040.

Sairam, R.K., Rao, K.V. and Srivastava, G.C. (2002) Differential response of wheat genotypes to long term salinity stress in relation to oxidative stress, antioxidant activity and osmolyte concentration. Plant Sci. 163, 1037-1046.

Scedecore, C.W. and Cochran, W.G. (1982) "Statistical
Methods", $7^{\text {th }}$ ed., Oxford and IBH Publishing Co. New Delhi.

Shehata, M.M. and EL-Khawas, S.A. (2003) Effect of two bio-fertilizers on growth parameters, yield characters, nitrogenous components, nucleic acids content, minerals, oil content, protein profiles and DNA banding pattern of sunflower yield. Pakistan J. Biol. Sci. 6(14), 1257-1268.

Snider, J.L., Oosterhuis, D.M. and Kawakami, E.M. (2010) Genotypic differences in thermotolerance are dependent upon prestress capacity for antioxidant protection of the photosynthetic apparatus in Gossypium hirsutum. Physiol. Plant, 138, 268-277.

Sun, T. and Gubler, F. (2004) Molecular mechanism of gibberellin signaling in plants. Ann. Rev.Plant Bio. 55, 197-223.

Suzuki, N. and Mittler, R. (2006) Reactive oxygen species and temperature stresses: A delicate balance between signalling and destruction. Physiol. Planta, 126, 45-51.

Van, R.S.J., Daniels, W.M., van, Z.J.M. and Taljaard, J.J. (2000) A comparative study of the effects of cholesterol, beta-sitosterol, beta-sitosterol glucoside, dehydroepiandrosteronesulphate and melatonin on in vitro lipid peroxidation. Metab. Brain Dis. 15, 257-265.

Vardhini, B.V. and Rao, S.S.R. (2003) Amelioration of osmotic stress by brassinosteroids on seed germination and seedling growth of three varieties of sorghum. Plant Growth Regul. 41, 25-31.

Molecular identification and genetic analysis for 24 turf-type Cynodon cultivars by sequence-related amplified polymorphism markers. Sci. Hortic. 122, 461-467.

Williams, J.C.K., Kubelik, A.R., Livak, K.J., Rafalsk, J.A. and Tingey, S.V. (1990) DNA polymorphism by arbitrary primers are useful as genetic markers. Nucleic Acids Res. 18(22), 6531-6535.

Yamaguchi, K., Mori, H. and Nishimura, M. (1995) A novel isoenzyme of ascorbate peroxidase localized onglyoxysomal and leaf peroxisomal membranes in pumpkin. Plant and Cell Physiol. 36, 1157-1162.

Yang, R.Y., Tsou, S.C.S., Lee, T.C., Chang, L.C., Kuo, 
G. and Lai, P.Y. (2006) Moringa, a novel plant rich in antioxidants, bioavailable iron, and nutrients. In: "Challenges in Chemistry and Biology of Herbs", C.T. Ho (Ed.), pp. 224-239.

Yang, X. and Quiros, C. (1993) Identification and classification of celery cultivars with RAPD markers. Theoreti. App. Gene. 86(2), 205-212.

Yuzbasioglu, E., Ozcan, S. and Acik., L. ( 2006) Analysis of genetic relationships among Turkish cultivars and breeding lines of Lens culinaris
Medik using RAPD markers. Genet. Resour. Crop Ev. 53, 507-514.

Zhou, R., Kjær, K.H., Rosenqvist, E., Yu, X., Wu, Z. and Ottosen, C. (2016) Physiological response to heat stress during seedling and anthesis stage in tomato genotypes differing in heat tolerance. $J$. Agro. Crop. Sci., ISSN 0931-2250.

(Received 1/ $1 / 2018$; accepted $27 / 2$ /2018)

\section{دور كلا من بيتا-سيتوستيرول أو حمض الجبريليك في وقاية اصناف نبات الطماطم

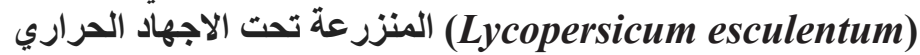

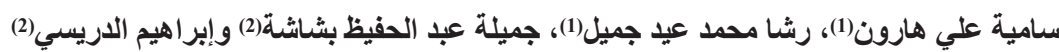

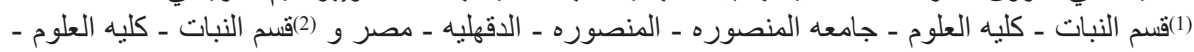 جامعه بنى غازي - بنى غازى - ليبيا.}

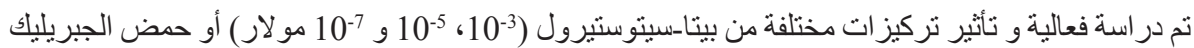

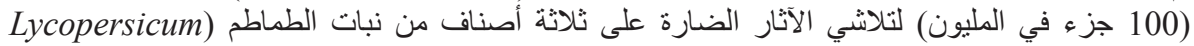

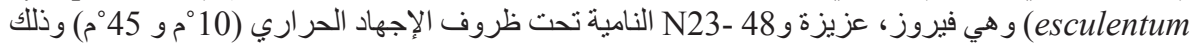

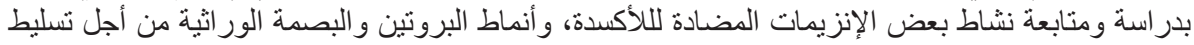

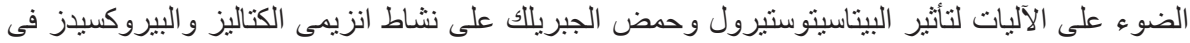

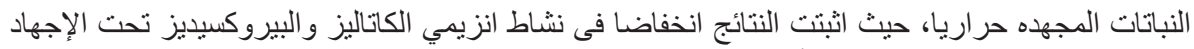

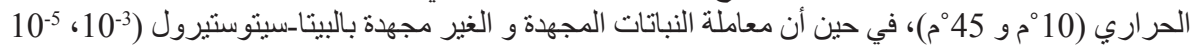

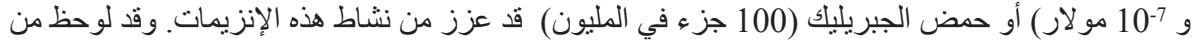

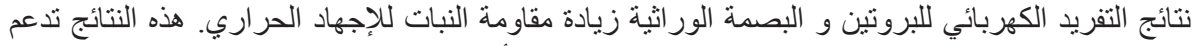

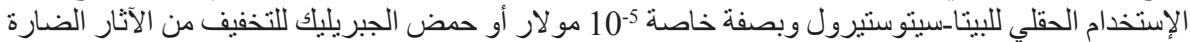
للإجهاد الحر اري على نبات الطماطح. 